\title{
Problem-Based Learning Model with Video Media to Improve Writing Skills
}

\author{
F Siburian ${ }^{1 *}$, Sutama $^{2^{*}}$ (iD) \\ 1,2 Jurusan Pendidikan Bahasa Indonesia, Universitas Pendidikan Ganesha, Singaraja, Indonesia \\ *Corresponding author: suburianf43@gmail.com
}

\begin{abstract}
Abstrak
Siswa kurang tertarik menulis karena guru cenderung menggunakan buku teks sebagai satu-satunya media dalam pembelajaran. Hal ini berdampak pada kemampuan menulis siswa yang rendah. Tujuan penelitian ini yaitu untuk menganalisis model pembelajaran berbasis masalah berbantuan video pembelajaran. untuk meningkatkan keterampilan menulis teks tanggapan kritis. Jenis penelitian ini yaitu penelitian tindakan kelas. Penelitian ini mengikuti tahap-tahap penelitian tindakan kelas yang masing-masing siklus terdiri atas empat tahap yaitu perencanaan, tindakan, observasi, serta refleksi. Subjek penelitian ini adalah siswa kelas IX sejumlah 28 siswa. Metode yang Metode yang digunakan untuk mengumpulkan data yaitu observasi, wawancara, dan tes. Instrumen yang digunakan untuk mengumpulkan data yaitu kuesioner dan lembar tes. Analisis data yang digunakan dalam penelitian ini adalah analisis deskriptif kualitatif dan deskriptif kuantitatif. Hasil penelitian menunjukkan bahwa penerapan model pembelajaran berbasis masalah dibantu media video dapat meningkatkan keterampilan menulis teks tanggapan kritis siswa. Peningkatan skor rata-rata keterampilan menulis teks tanggapan kritis adalah sebesar 11, yaitu dari rata-rata 80 menjadi 91. Jadi, pembelajaran dapat dikatakan berhasil karena secara keseluruhan siswa tuntas. Siswa juga memberikan respons yang sangat positif dalam mengikuti pembelajaran menulis teks tanggapan kritis melalui penerapan model pembelajaran berbasis masalah dibantu media video yakni dengan skor 22,89 .
\end{abstract}

Kata kunci: PBM, Video, menulis

\section{Abstract}

Students are less interested in writing because teachers tend to use textbooks as the only medium in learning. This has an impact on students' low writing skills. The purpose of this study is to analyze the problem-based learning model assisted by video learning. to improve critical response text writing skills. This type of research is classroom action research. This study follows the stages of classroom action research, each cycle consisting of four stages, namely planning, action, observation, and reflection. The subjects of this research were 28 students of class IX. Methods The methods used to collect data are observation, interviews, and tests. The instruments used to collect data are questionnaires and test sheets. The data analysis used in this research is descriptive qualitative and quantitative descriptive analysis. The results showed that the application of the problem-based learning model assisted by video media could improve students' critical response text writing skills. The increase in the average score of critical response text writing skills is 11, from an average of 80 to 91 . So, learning can be said to be successful because overall, students are complete. Students also gave a very positive response in participating in learning to write critical response texts by applying a problem-based learning model assisted by video media with a score of 22.89 .

Keywords: PBM, Video, writing

\begin{tabular}{lll}
\hline History: & & Publisher: Undiksha Press \\
Received & : March 19, 2021 & Licensed: This work is licensed under \\
Revised & : March 21, 2021 & a Creative Commons Attribution 3.0 License \\
Accepted & : June 10, 2021 & Published \\
: July 25, 2021 &
\end{tabular}

\section{Introduction}

The 2013 curriculum for learning Indonesian wants students to be more productive, creative, innovative, and active (Dwiasih \& Agung, 2021; Mulyadin, 2016). Indonesian language learning in the 2013 curriculum uses a text-based approach. This text-based learning trains students to solve the problems they face critically by expressing thoughts or ideas outlined in the form of writing/products in the form of text (Febriyanti, 2013; Mustikaningrum et al., 2020). Of the four language skills, one aspect of language skills related to expressing thoughts, ideas, opinions, and feelings is writing skills menulis (Azmussya'ni \& Wangid, 2014; Salfera, 2017). Writing is a person's peak language skill, 
which includes choosing vocabulary, using sentence structures, applying spelling and punctuation, organizing ideas coherently, using a variety of effective sentences, and producing writing (Masrur et al., 2020; Staples et al., 2013). Writing is one of the language skills to express ideas in written form (Hill et al., 2020; Su et al., 2021).

Today's problem is that many students lack writing skills (Pen et al., 2020; Vassilaki, 2017). The observations made at SMP Negeri 1 Singaraja class IX showed that the average score obtained by students for learning materials for writing critical response texts was 78, while the KKM score was 80 . In addition, $40 \%$ of students scored below the KKM. This is an indisputable fact about the low ability of students to write critical response texts. Furthermore, interviews with teachers in the field of Indonesian studies found that the following things influenced the low ability of students in writing critical response texts. First, the students' lack of knowledge about critical response texts. Second, students have difficulty in expressing their responses to the topics discussed. Third, students find it challenging to translate their ideas into sentences. Fourth, students have difficulty writing the contents of the critical response text according to the structure and linguistic elements.

The interviews conducted with several students obtained data that students were less interested in writing because teachers tend to use textbooks as the only medium in learning. The lack of learning media will make it difficult for students to learn (Mayer, 2020; Nonthamand, 2020). In addition, the work instructions given by the teacher are not clear. Writing critical response texts is classified as severe material and quite tricky for junior high school students in learning Indonesian. This statement was made because of several things. First, this material is a new material for students, given that this kind of material does not exist in the previous curriculum. Therefore, students are not used to writing texts (Kormasela et al., 2020; Owon, 2017). Second, the material for writing critical response texts is nonfiction writing material that is very tied to writing rules, so students must be careful in writing (Azmussya'ni \& Wangid, 2014; Salfera, 2017). Third, critical response texts must pay attention to the structure and features of the language. This third point is the most critical because the structure and linguistic features distinguish critical response texts from other texts (Nuryamah et al., 2016; Widyaningrum \& Hasanudin, 2019).

Writing as a form of language proficiency has excellent benefits for human life, especially for students (Darmawan et al., 2017; Szanto, 2020). At the time of writing, students are required to think in writing ideas based on their knowledge and experience (Abrams \& Byrd, 2016; Karaca \& Uysal, 2021). These activities require seriousness to process, organize, and consider critically the ideas that will be put into writing (Fu et al., 2019; Wong \& Russak, 2020). One of the competencies to be achieved in learning Indonesian for grade IX junior high school students in the 2013 curriculum is to compose or produce critical response texts. Critical response text is a text that contains a response, in the form of support or rejection, to a thing or event that is supported by data supporting the response. The critical response text contains responses of approval or rejection regarding an event or a problem that occurs accompanied by evidence. Students study critical response texts to train students to think critically and be sensitive to the problems around them (Oya \& Budiningsih, 2014; Sari, 2019).

The seriousness and difficulty of the material in writing critical response texts require teachers to package learning excitingly and appropriately so that students can compose critical response texts according to their provisions. About the difficulties experienced by students, one way that can be done to motivate and improve students' skills in writing critical response texts is to apply appropriate learning models with the help of exciting media (Blaschke \& Hase, 2019; Jain et al., 2021; Puspitarini \& Hanif, 2019). The learning model referred to here is a problem-based learning model. With the problem-based learning model, students will face real problems (Awaludin et al., 2020; Mutakinati et al., 2018). 
This will require students to think critically and actively and have extensive knowledge in solving problems (Balan et al., 2019; Marzuki \& Basariah, 2017). The problem-based learning model is used to stimulate students' higher-order thinking in realworld problem-oriented situations, including learning how to learn (Bosica et al., 2021; Duncan et al., 2013). To support this, students must dig up information from various sources. The problem-based learning model creates a vibrant, independent, and meaningful learning atmosphere (Aufa et al., 2021; Gholami et al., 2021).

The application of this problem-based learning model will be better if learning media assists it, one of which is by using video media (Andriyani \& Suniasih, 2021; Puspitarini \& Hanif, 2019). Video is one learning medium that can display audio and visual elements to make it easier for students to learn (Colasante \& Douglas, 2016; Nonthamand, 2020).Video media is used to bring up authentic problems to students (Rubini et al., 2018; Van Alten et al., 2019). Video media will make it easier for students to analyze problems and more effortless to express ideas and ideas in written form in a coherent manner so that students will be more enthusiastic in participating in learning activities (Kamelia, 2019; Teng, 2019).

The findings of previous studies also stated that learning videos would help students learn (Priantini, 2020; Yildiz \& Ersan, 2011). Other research findings also state that the problem-based learning model will increase students' enthusiasm for learning to improve student understanding (Koh et al., 2010; Phungsuk et al., 2017; Silwana et al., 2020). The absence of an in-depth study of the problem-based learning model assisted by video learning can improve writing critical response texts. The purpose of this study is to analyze the problem-based learning model assisted by video learning. It is hoped that the problem-based learning model with the help of learning videos can help students learn so that they can improve their critical response text writing skills.

\section{Methods}

This type of research is classroom action research. This study follows the stages of classroom action research, each cycle consisting of four stages, namely planning, action, observation, and reflection. This research was conducted at SMP Negeri 1 Singaraja. Subjects in this study were 28 students. The methods used to collect data are observation, interviews, and tests. The instruments used to collect data are questionnaires and test sheets.

The data analysis used in this research is descriptive qualitative and quantitative descriptive analysis. Data on critical response text writing skills were analyzed descriptively quantitatively. Data regarding the learning steps were analyzed descriptively qualitatively. Data on student responses were analyzed quantitatively. The success criteria used as a benchmark in ending this research are as follows. First, the criteria for the success of learning critical response text writing skills. In determining the value of this critical response text writing skill, a conversion guide with a scale of one hundred is used as described in table 1, which is as follows.

Table 1. Conversion Guidelines

\begin{tabular}{cc}
\hline Value & Rating \\
\hline Very good & $90<\mathrm{AB} \leq 100$ \\
Well & $80<\mathrm{B} \leq 90$ \\
Enough & $70<\mathrm{C} \leq 80$ \\
Not enough & $\leq 70$ \\
\hline & (Arikunto, 2008:19)
\end{tabular}


Based on the formulation and conversion guidelines above, students are said to understand the subject matter if the minimum score obtained by students is 80 (good). Classically, this research is complete if $100 \%$ of the students scored 80 and above or were in a suitable category. If $100 \%$ of the total number of students score 80 and above or are in the good category, the research can be said to be complete, and the research can be stopped.

The criteria for student responses are indicated by acquiring a percentage of $80 \%$ of the total number of students responding positively or happy with the learning action. For more details, the following explanation. Analysis of the data obtained through the questionnaire was based on the average score of student responses (X), the ideal mean (Mi), and the ideal standard deviation (SDi). Research on student responses is considered successful if $80 \%$ of students give a positive response. With the achievement of the above success criteria, the study was discontinued. The cycle of actions that can achieve these success criteria are at the same time considered the best actions.

\section{Results and Discussion Result}

This research has been conducted in two cycles. In cycles, I and II, learning to write critical response texts was carried out according to the steps of the problem-based learning model assisted by video media. The results of the first cycle research showed that the score of students in writing critical response texts on good criteria was 19 people (67.9\%), five people (17.8\%) enough, and four people less $(14.3 \%)$. The average value of students' critical response text writing skills learning outcomes in the classical cycle $\mathrm{I}$ is 80 , is at 71-80 with Enough criteria or $\mathrm{C}$ predicate but does not meet the Classical Minimum Completeness Criteria (KKM), which is $100 \%$. It can be concluded, the research in the first cycle has not been successful because of the 28 students. There are still nine students who have not met the KKM 80 according to the one applicable at SMP Negeri 1 Singaraja. In addition to the value of writing skills, data on student responses were also obtained, namely: 7 students with a percentage of $25 \%$ had a very positive response, 21 students with a percentage of $75 \%$ had a positive response, and no students had a positive enough, less favorable or very poor response. Positive.

Furthermore, reflection is carried out by paying attention to student learning outcomes in cycle I. The problems encountered can be seen from the following explanations: (1) the student worksheets given by the teacher are less able to represent the contents of the ideas that students will convey; (2) students have not been able to use the linguistic elements of critical response texts well; (3) students still make spelling and punctuation errors when writing critical response texts; and (4) the explanation from the teacher is still not optimal. Based on these problems, the corrective actions taken were: (1) researchers improved student worksheets, (2) provided guidance to students who were still having difficulties and incorrectly using linguistic and spelling elements in the text they made, and (3) the teacher gave an explanation - more detail to students.

These improvements were made in the second cycle so that in the second cycle learning to write critical response texts showed that the score in writing critical response texts of students on the criteria was very good 11 people $(39.3 \%$ ), good 13 people $46.4 \%$, and entirely 4 people $(14,3 \%)$. Based on the data above, it can be concluded that the average score of students' critical response text writing skills learning outcomes in cycle II classically increased by 11 points from 80 to 91 and was at 91-100 with criteria Very Good or predicate A and already met the criteria. Minimum completeness (KKM) classically is $100 \%$.

In cycle II, data on student responses were also obtained as follows: 19 students with a percentage of $67.9 \%$ had a very positive response, 9 students with a percentage of $32.1 \%$ had a positive response, and no students had a moderately positive response, less positive or 
significantly less optimistic. Based on the learning outcomes data, it can be seen that all students are complete, and it can be stated that the critical response text writing skills of students in grades IX-A8 SMP Negeri 1 Singaraja from cycle I to cycle II have increased and are thriving.

\section{Discussion}

When learning using a problem-based learning model makes students very enthusiastic about participating in learning. In addition, this learning model trains and develops the ability to solve problems oriented to authentic problems from students' actual lives to stimulate higher-order thinking skills (Mutakinati et al., 2018; Rozhana \& Harnanik, 2019). This problem-based learning model becomes a learning approach that seeks to apply problems that occur in the real world so that students are enthusiastic about participating in learning (Balan et al., 2019; Marzuki \& Basariah, 2017). Teaching and learning activities with the Problem Based Learning model begin by giving a problem (Aufa et al., 2021; Silwana et al., 2020). Students can also practice thinking critically and gain problem-solving skills, and it is unforgettable to gain knowledge and essential concepts from the teaching material discussed (Bosica et al., 2021; Huang et al., 2020).

In addition, learning models combined with appropriate learning media will improve the student learning atmosphere (Arianti et al., 2019; Dames et al., 2019; Lestari et al., 2017). Learning media can facilitate students ' learning (Kamelia, 2019; Lai \& Tai, 2021). In applying problem-based learning models, also use learning videos so that students feel happy in learning. Without the help of the media, the learning materials are difficult for students to understand and understand, incredibly complex and complex learning (Jogezai et al., 2021; Saripudin et al., 2018). The video media used can help students learn because it contains audio and visual elements to facilitate students who have different learning styles (Gabriele et al., 2016; Layona et al., 2017). This media can increase students' interest in learning because students can listen and see pictures simultaneously. The ability of video to depict live images and sound gives it its charm (Ayu et al., 2020; Tseng, 2021; Valle et al., 2019). It makes students motivated to learn to improve students' writing skills.

The findings of previous studies also stated that learning videos could improve student learning outcomes (Hanif, 2020; Nurrohmah et al., 2018; Ompi et al., 2020). In addition, other studies also state that learning videos increase students' enthusiasm for learning (Pamungkas et al., 2018; Rose et al., 2016). Other research also states that problembased learning models can improve critical thinking skills and student learning outcomes(Priani et al., 2019; Rahayu \& Fahmi, 2018). So it can be concluded that the problem-based learning model assisted by learning videos can help students learn. This research implies that teachers can apply a problem-based learning model assisted by learning videos to improve their critical response text writing skills.

\section{Conclusion}

Student responses were very positive towards the application of the problem-based learning model assisted by video media. The application of the problem-based learning model assisted by video media can improve writing critical response texts in class IX-A8 students of SMP Negeri 1 Singaraja.

\section{References}

Abrams, Z. I., \& Byrd, D. R. (2016). The effects of pre-task planning on L2 writing: Mindmapping and chronological sequencing in a 1st-year German class. System, 63. https://doi.org/10.1016/j.system.2016.08.011 
Andriyani, N. L., \& Suniasih, N. W. (2021). Development Of Learning Videos Based On Problem-Solving Characteristics Of Animals And Their Habitats Contain in Science Subjects On 6th-Grade. Journal of Education ..., 5(1), 37-47. https://doi.org/10.23887/jet.v5i1.32314

Arianti, Wiarta, \& Darsana. (2019). Pengaruh Model Pembelajaran Problem Posing Berbantuan Media Semi Konkret terhadap Kompetensi Pengetahuan Matematika. Jurnal Ilmiah Sekolah Dasar, 3(4). https://doi.org/10.23887/jisd.v3i4.21765

Aufa, M. N., Rusmansyah, R., Hasbie, M., Jaidie, A., \& Yunita, A. (2021). The Effect of Using e-module Model Problem Based Learning (PBL) Based on Wetland Environment on Critical Thinking Skills and Environmental Care Attitudes. Jurnal Penelitian Pendidikan IPA, 7(3), 401-407. https://doi.org/10.29303/jppipa.v7i3.732

Awaludin, Wibawa, \& Winarsih. (2020). Integral Calculus Learning Using Problem Based Learning Model Assisted by Hypermedia-Based E-Book. Jurnal Pendidikan Indonesia, 9(2). https://doi.org/10.23887/jpi-undiksha.v9i2.23106

Ayu, D., Manu, M., \& Priantini, O. (2020). The Development Of Teaching Video Media Based On Tri Kaya Parisudha In Educational Psychology Courses. Journal of Education Technology, 4, 448-455. http://dx.doi.org/10.23887/jet.v4i4.29608.

Azmussya'ni, \& Wangid, M. N. (2014). Peningkatan Keterampilan Menulis Menggunakan Pendekatan Proses Dengan Media Gambar Di Sdn 3 Sakra. Jurnal Prima Edukasia, 2(1), 1-13. https://doi.org/10.21831/jpe.v2i1.2640

Balan, L., Yuen, T., \& Mehrtash, M. (2019). Problem-Based Learning Strategy for CAD Software Using Free-Choice and Open-Ended Group Projects. Procedia Manufacturing, 32, 339-347. https://doi.org/10.1016/j.promfg.2019.02.223

Blaschke, L. M., \& Hase, S. (2019). Heutagogy and digital media networks: Setting students on the path to lifelong learning. Pacific Journal of Technology Enhanced Learning, 1(1), 1-14. https://doi.org/10.24135/pjtel.v1i1.1

Bosica, J., Pyper, J. S., \& MacGregor, S. (2021). Incorporating problem-based learning in a secondary school mathematics preservice teacher education course. Teaching and Teacher Education, 105. https://doi.org/10.1016/j.tate.2021.103335

Colasante, M., \& Douglas, K. (2016). Prepare-participate-connect: Active learning with video annotation. Australasian Journal of Educational Technology, 32(4), 68-91. https://doi.org/10.14742/ajet.2123

Dames, I., Koeswanti, H. D., \& Radia, E. H. (2019). Penerapan Model Examples Non Examples Berbantuan Media Gambar Untuk Meningkatkan Hasil Belajar Pada Tema 1 Siswa Kelas 5 SDN Sidorejo Lor 05. Jurnal Basicedu, 3(1). https://doi.org/10.31004/basicedu.v3i2.59

Darmawan, D., Setiawati, P., Supriadie, D., \& Alinawati, M. (2017). Penggunaan Multimedia Pembelajaran Interaktif Untuk Meningkatkan Keterampilan Menulis English simple Sentences pada Mata Kuliah Basic Writing Di Stkip Garut. Pedagogia, 15(1), 109. https://doi.org/10.17509/pedagogia.v15i1.6576

Duncan, M. J., Smith, M., \& Cook, K. (2013). Implementing online problem based learning (PBL) in postgraduates new to both online learning and PBL: An example from strength and conditioning. Journal of Hospitality, Leisure, Sport and Tourism Education, 12(1), 79-84. https://doi.org/10.1016/j.jhlste.2012.11.004

Dwiasih, A. A. I., \& Agung, A. A. G. (2021). The Development of Fabel E-Comic in Bahasa Indonesia Lesson for Grade II of Elementary School. Advances in Social Science, Education and Humanities Research. https://doi.org/10.2991/assehr.k.210407.284

Febriyanti. (2013). Article Kurikulum Pendidikan Tinggi Di Era Globalisasi (Pergeseran Dari Kurikulum Inti Dan Institusional Ke Kurikulum Berbasis Kompetensi). Ta'di Jurnal Pendidikan Islam, 18(2). https://doi.org/10.19109/tjie.v18i02.51. 
Fu, Q.-K., Lin, C.-J., Hwang, G.-J., \& Zhang, L. (2019). Impacts of a mind mapping-based contextual gaming approach on EFL students' writing performance, learning perceptions and generative uses in an English course. Computers \& Education, 137. https://doi.org/10.1016/j.compedu.2019.04.005

Gabriele, K. M., Holthaus, R. M., \& Boulet, J. R. (2016). Usefulness of Video-Assisted Peer Mentor Feedback in Undergraduate Nursing Education. Clinical Simulation in Nursing, 12(8), 337-345. https://doi.org/10.1016/j.ecns.2016.03.004

Gholami, M., Changaee, F., Karami, K., Shahsavaripour, Z., Veiskaramian, A., \& Birjandi, M. (2021). Effects of multiepisode case-based learning (CBL) on problem-solving ability and learning motivation of nursing students in an emergency care course. Journal of Professional Nursing, 37(3). https://doi.org/10.1016/j.profnurs.2021.02.010

Hanif, M. (2020). The development and effectiveness of motion graphic animation videos to improve primary school students' sciences learning outcomes. International Journal of Instruction, 13(4), 247-266. https://doi.org/10.29333/iji.2020.13416a

Hill, C., Khoo, S., \& Hsieh, Y.-C. (2020). An investigation into the learning transfer of English for specific Academic Purposes (ESAP) writing skills of students in Singapore. Journal of English for Academic Purposes, 46. https://doi.org/10.1016/j.jeap.2020.100908

Huang, S. Y., Kuo, Y. H., \& Chen, H. C. (2020). Applying digital escape rooms infused with science teaching in elementary school: Learning performance, learning motivation, and problem-solving ability. Thinking Skills and Creativity, 37(129), 100681. https://doi.org/10.1016/j.tsc.2020.100681

Jain, R., Gupta, M., Jain, K., \& Kang, S. (2021). Deep learning based prediction of COVID19 virus using chest X-Ray. Journal of Interdisciplinary Mathematics, 24(1), 155-173. https://doi.org/10.1080/09720502.2020.1833460

Jogezai, N. A., Baloch, F. A., Jaffar, M., Shah, T., Khilji, G. K., \& Bashir, S. (2021). Teachers' Attitudes Towards Social Media (SM) Use in Online Learning Amid The COVID-19 Pandemic: The Effects of SM Use by Teachers and Religious Scholars During Physical Distancing. Journal Heliyon, 7(4), 1-9. https://doi.org/10.1016/j.heliyon.2021.e06781

Kamelia, K. (2019). Using Video as Media of Teaching in English Language Classroom: Expressing Congratulation and Hopes. Utamax: Journal of Ultimate Research and Trends in Education, 1(1), 34-38. https://doi.org/10.31849/utamax.v1i1.2742

Karaca, M., \& Uysal, H. H. (2021). The development and validation of an inventory on English writing teacher beliefs. Assessing Writing, 47. https://doi.org/10.1016/j.asw.2020.100507

Koh, J. H. L., Herring, S. C., \& Hew, K. F. (2010). Project-based learning and student knowledge construction during asynchronous online discussion. Internet and Higher Education, 13(4), 284-291. https://doi.org/10.1016/j.iheduc.2010.09.003

Komala, F. nur. (2016). Pembelajaran IPA Sekolah Dasar. Ediide Indografika.

Kormasela, D. A., Dawud, D., \& Rofi'uddin, A. H. (2020). Pemanfaatan Kearifan Lokal Maluku dalam Pengembangan Bahan Ajar Menulis Teks Prosedur untuk Siswa Kelas VII. Jurnal Pendidikan: Teori, Penelitian, Dan Pengembangan, 5(8), 1056-1065. https://doi.org/10.17977/jptpp.v5i8.13872

Lai, C., \& Tai, C.-P. (2021). Types of social media activities and Hong Kong South and Southeast Asians Youth's Chinese language learning motivation. System, 97. https://doi.org/10.1016/j.system.2020.102432

Layona, R., Yulianto, B., \& Turnadi, Y. (2017). Authoring Tool for Interactive Video Content for Learning Programming. Procedia Computer Science, 116, 37-44. https://doi.org/10.1016/j.procs.2017.10.006 
Lestari, Negara, \& Ganing. (2017). Pengaruh Model Pembelajaran Word Square Berbantuan Media Lingkungan terhadap Kompetensi Pengetahuan IPA Siswa. MIMBAR PGSD Undiksha, 5(2), 9. https://doi.org/10.23887/jjpgsd.v5i2.10731

Marzuki, \& Basariah. (2017). The Influence Of Problem-Based Learning And Project Citizen Model In The Civic Education Learning On Student'scritical Thinking Ability And Self Discipline. Cakrawala Pendidikan, 6(3), 382-400. https://journal.uny.ac.id/index.php/cp/article/view/14675/pdf.

Masrur, I., Irawati, E., \& Sulistyo, G. H. (2020). Integrating Writing Process with Quantum Learning Framework in English Language Teaching. Jurnal Pendidikan: Teori, Penelitian, Dan Pengembangan, 5(3). https://doi.org/10.17977/jptpp.v5i3.13262

Mayer, R. E. (2020). Where is the learning in mobile technologies for learning? $\begin{array}{llll}\text { Contemporary Educational } & \text { Psychology, } & 60, & 101824 .\end{array}$ https://doi.org/10.1016/j.cedpsych.2019.101824

Mulyadin. (2016). Implementasi Kebijakan Pembelajaran Tematik Terpadu Kurikulum 2013 di SDN Kauman 1 Malang dan SD Muhammadiyah 1 Malang. Jurnal Pendidikan Edutama, 3(2), 31-48. https://doi.org/10.30734/jpe.v3i2.35.

Mustikaningrum, G., Pramusinta, L., Ayu, S., \& Umar, M. (2020). Implementasi Pendidikan Karakter Terintegrasi Kurikulum Dan Metode Pembelajaran Pada Masa Pandemi Covid19. AULADUNA: Jurnal Pendidikan Dasar Islam, 7(2), 154-164. https://doi.org/10.24252/10.24252/auladuna.v7i2a5.2020

Mutakinati, L., Anwari, I., \& Yoshisuke, K. (2018). Analysis of students' critical thinking skill of middle school through stem education project-based learning. Jurnal Pendidikan IPA Indonesia, 7(1), 54-65. https://doi.org/10.15294/jpii.v7i1.10495

Nonthamand, N. (2020). Guideline to develop an instructional design model using video conference in open learning. International Journal of Emerging Technologies in Learning, 15(3), 140-155. https://doi.org/10.3991/ijet.v15i03.10842

Nurrohmah, F., Putra, F. G., \& Farida, F. (2018). Development of Sparkol Video Scribe Assisted Learning Media. Formatif: Jurnal Ilmiah Pendidikan MIPA, 8(3), 233-250. https://doi.org/10.30998/formatif.v8i3.2613

Nuryamah, I., Sunarya, D. T., \& Irawati, R. (2016). Upaya Meningkatkan Keterampilan Menulis Permulaan Dalam Melengkapi Cerita Rumpang Menggunakan Media Gambar Dan Papan Bergaris. Jurnal Pena Ilmiah, 1(1), 761-770. https://doi.org/10.17509/jpi.v1i1.3566

Ompi, Sompie, \& Sugiarso. (2020). Video animasi interaktif 3d dampak penggunaan gadget pada anak sekolah dasar tingkat awal. Jurnal Teknik Elektro Dan Komputer, 9(2). https://doi.org/10.35793/jtek.9.2.2020.29717

Owon, R. A. S. (2017). Pengembangan Bahan Ajar Menulis Berbagai Jenis Teks Bertema Kearifan Lokal Sikka Bagi Siswa SMP. Jurnal Inovasi Pembelajaran, 3(1), 528-541. https://doi.org/10.22219/jinop.v3i1.4318

Oya, R. N., \& Budiningsih, C. (2014). Peningkatan Motivasi Belajar dan Hasil Belajar Bahasa Indonesia Menggunakan Model Pembelajaran Kreatif dan Produktif. Jurnal Prima Edukasia, 2(1). https://doi.org/10.21831/jpe.v2i1.2649.

Pamungkas, A. S., Ihsanudin, I., Novaliyosi, N., \& Yandari, I. A. V. (2018). Video Pembelajaran Berbasis Sparkol Videoscribe: Inovasi Pada Perkuliahan Sejarah Matematika. Prima: Jurnal Pendidikan Matematika, 2(2), 127. https://doi.org/10.31000/prima.v2i2.705

Pen, T. T.-L., Marchand, C., Léocadie, M., \& Rothan-Tondeur, M. (2020). Reflective writing: Implementation and learning perception from students and teachers of French nursing schools. Nurse Education in Practice, 49. https://doi.org/10.1016/j.nepr.2020.102921 
Phungsuk, R., Viriyavejakul, C., \& Ratanaolarn, T. (2017). Development of a problem-based learning model via a virtual learning environment. Kasetsart Journal of Social Sciences, 38(3), 297-306. https://doi.org/10.1016/j.kjss.2017.01.001

Priani, I., Manuaba, I. B. S., \& Darsana, I. W. (2019). Pengaruh Model Problem Based Learning (PBL) Berbantuan Media Gambar Terhadap Hasil Belajar IPA Siswa Kelas V Gugus III Kuta Utara Tahun Pelajaran 2017/2018. Mimbar PGSD, 7(1). https://doi.org/10.23887/jjpgsd.v7i1.16972

Priantini, D. A. (2020). The Development Of Teaching Video Media Based On Tri Kaya Parisudha In Educational Psychology Courses. Journal of Education Technology, 4(4). https://doi.org/10.23887/jet.v4i4.29608

Puspitarini, Y. D., \& Hanif, M. (2019). Using Learning Media to Increase Learning Motivation in Elementary School. Anatolian Journal of Education, 4(2), 53-60. https://doi.org/10.29333/aje.2019.426a

Rahayu, E., \& Fahmi, S. (2018). Efektivitas penggunaan model problem based Learning (PBL) dan inkuiri terhadap hasil belajar matematika siswa SMP N 1 Kasihan Kabupaten Bantul semester genap tahun ajaran 2017/2018. JURING (Journal for Research in Mathematics Learning), 1(2), 147. https://doi.org/10.24014/juring.v1i2.5671

Rose, J. A., O’Meara, J. M., Gerhardt, T. C., \& Williams, M. (2016). Gamification: using elements of video games to improve engagement in an undergraduate physics class. Physics Education, 51(5). https://doi.org/10.1088/0031-9120/51/5/055007

Rozhana, K. M., \& Harnanik, H. (2019). Lesson Study dengan Metode Discovery Learning dan Problem Based Instruction. Intelegensi: Jurnal Ilmu Pendidikan, 1(2). https://doi.org/10.33366/ilg.v1i2.1355

Rubini, B., Permanasari, A., \& Yuningsih, W. (2018). Learning Multimedia Based on Science Literacy on the Lightning Theme. Jurnal Penelitian Dan Pembelajaran IPA, 4(2), 89-104. https://doi.org/10.30870/jppi.v4i2.3926

Salfera, N. (2017). Meningkatkan Kemampuan Menulis Teks Eksplanasi Dengan Menggunakan Media Gambar Berseri Pada Siswa Kelas VII. Jurnal EDUCATIO: Jurnal Pendidikan Indonesia, 3(2). https://doi.org/10.29210/12017295

Sari, P. A. P. (2019). Hubungan Literasi Baca Tulis Dan Minat Membaca Dengan Hasil Belajar Bahasa Indonesia. Journal for Lesson and Learning Studies, 3(1). https://doi.org/10.23887/j1ls.v3i1.24324

Saripudin, E., Sari, I., \& Mukhtar, M. (2018). Using Macro Flash Animation Media on Motion Material to Improve Learning Achievement for Learning Science in Junior High School. , 4 (1),. Journal of Science Research and Learning, 4(1), 68-75. https://doi.org/10.30870/jppi.v4i1.3316

Silwana, A., Subanji, S., Manyunu, M., \& Rashahan, A. A. (2020). Students' Responses Leveling in Solving Mathematical Problem Based on SOLO Taxonomy Viewed from Multiple Intelligences. Indonesian Journal on Learning and Advanced Education (IJOLAE), 3(1), 1-16. https://doi.org/10.23917/ijolae.v3i1.10528

Staples, S., Egbert, J., Biber, D., \& McClair, A. (2013). Formulaic sequences and EAP writing development: Lexical bundles in the TOEFL iBT writing section. Journal of English for Academic Purposes, 12(3). https://doi.org/10.1016/j.jeap.2013.05.002

Su, H., Zhang, Y., \& Lu, X. (2021). Applying local grammars to the diachronic investigation of discourse acts in academic writing: The case of exemplification in Linguistics research articles. English for Specific Purposes, 63. https://doi.org/10.1016/j.esp.2021.05.002

Szanto, B. (2020). Reading and Writing Comprehension in the Mother Tongue in the Romanian National Assessment - Objectives, Tests, Results. Technium Social Science Journal, 9. https://doi.org/10.47577/tssj.v9i1.933 
Teng, (Mark) Feng. (2019). The effects of video caption types and advance organizers on incidental L2 collocation learning. Computers \& Education, 142. https://doi.org/10.1016/j.compedu.2019.103655

Tseng, S. (2021). The influence of teacher annotations on student learning engagement and video watching behaviors. International Journal of Educational Technology in Higher Education, 18(1), 1-17. https://doi.org/10.1186/s41239-021-00242-5

Valle, S. C., Støen, R., Sæther, R., \& Sæther, R. (2019). Test-retest reliability of computerbased video analysis of general movements in healthy term-born infants. Early Human Development, 91(10). https://doi.org/10.1016/j.earlhumdev.2015.07.001

Van Alten, D. C. D., Phielix, C., Janssen, J., \& Kester, L. (2019). Effects of flipping the classroom on learning outcomes and satisfaction: A meta-analysis. Educational Research Review, 28(June), 1-18. https://doi.org/10.1016/j.edurev.2019.05.003

Vassilaki, E. (2017). Reflective writing, reflecting on identities: The construction of writer identity in student teachers' reflections. Linguistics and Education, 42. https://doi.org/10.1016/j.linged.2017.08.001

Widyaningrum, H. K., \& Hasanudin, C. (2019). Kajian Kesulitan Belajar Membaca Menulis Permulaan (MMP) di Sekolah Dasar [Study of Difficulty Learning to Read Beginning Writing (MMP) in Primary School]. Pedagogia: Jurnal Pendidikan, 8(2), 189-200. https://doi.org/10.21070/pedagogia.v8i2.2219

Wong, K. S. R., \& Russak, S. (2020). Hong Kong Cantonese L1 preschool children's name writing in English L2. Cognitive Development, 56. https://doi.org/10.1016/j.cogdev.2020.100957

Yildiz, S., \& Ersan, Y. (2011). A study on pc - video games in terms of the space awareness from childhood to youth. Procedia - Social and Behavioral Sciences, 28. https://doi.org/10.1016/j.sbspro.2011.11.145 